THE FEASIBILITY OF CREATING AND SUSTAINING CHARTER SCHOOLS IN

\title{
THE RURAL UNITED STATES
}

by

McAllister Hall

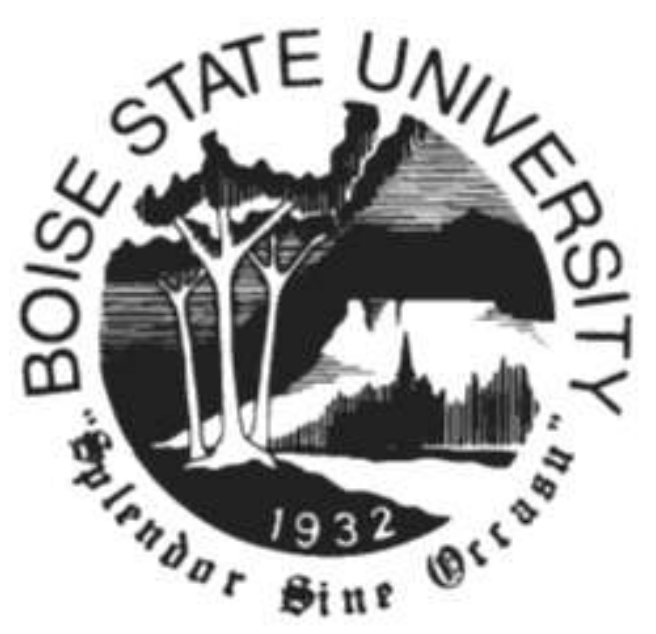

A thesis

submitted in partial fulfillment

of the requirements for the degree of

Master of Arts in Education, Curriculum and Instruction

Boise State University

May 2020 


\section{McAllister Hall \\ SOME RIGHTS RESERVED

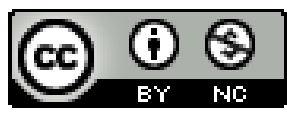

This work is licensed under a Creative

Commons Attribution-Noncommercial

4.0 International License. 


\title{
DEFENSE COMMITTEE AND FINAL READING APPROVALS
}

\author{
of the thesis submitted by
}

\section{McAllister Hall}

Thesis Title: The Feasibility of Creating and Sustaining Charter Schools in the Rural United States

Date of Final Oral Examination: $\quad 21$ February 2020

The following individuals read and discussed the thesis submitted by student McAllister Hall, and they have evaluated the student's presentation and response to questions during the final oral examination. They found that the student passed the final oral examination.

Phil Kelly, Ph.D.

Peter Boedeker, Ph.D.

Kathleen Budge, Ed.D.
Chair, Supervisory Committee

Member, Supervisory Committee

Member, Supervisory Committee

The final reading approval of the thesis was granted by Phil Kelly, Ph.D., Chair of the Supervisory Committee. The thesis was approved by the Graduate College 


\section{DEDICATION}

I could not have done this without the support of Spencer Ottley and Wes and

Lisa Hall. Other humans who provided much needed support include Katie Dean, Summer Giles, Ashley Allen and Ashley Gibby. Special thanks to Lucy, Peter, Annabelle, Calvin, Nora, Eleanor, Heidi and June Hall. 


\section{ACKNOWELEDGEMENTS}

Invaluable academic support was provided by the following: Phil Kelly, Peter

Bodeker, Kathleen Budge, Vanessa Fry, Ben Larsen, Lantz McGinnis-Brown, Ben Gibbs, Vaughn RA Call and C. Riley Nelson. 


\begin{abstract}
Many parents in rural areas desire to make a choice for their child to have an education different from what the local TPS can provide, but the choice is not available (McCarthy, 2016; Bagley, Woods, \& Glatter, 2001). Communities play a large role in the success of both TPSs and charter schools, especially in rural areas (Johnson \& Howley, 2015; Stuit \& Doan, 2012). In many cases, community characteristics impact student performance as much as the school characteristics (Bodine et al., 2008; Reeves, 2012). The research presented in this study acts as a feasibility study of the potential for rural communities across the U.S. to create and sustain charter schools, given their financial characteristics. This research adds to the national conversation of school choice by determining the accessibility and plausibility of U.S. students across the country, including those in rural areas, to have increased access to school choice options.
\end{abstract}




\section{TABLE OF CONTENTS}

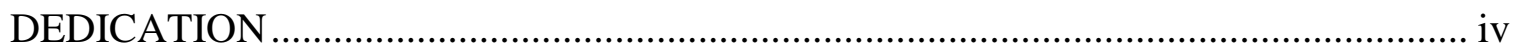

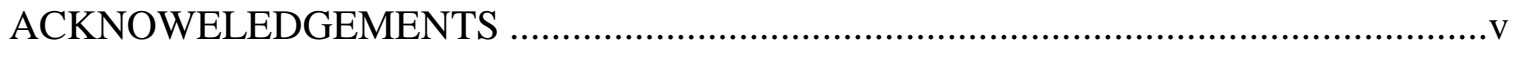

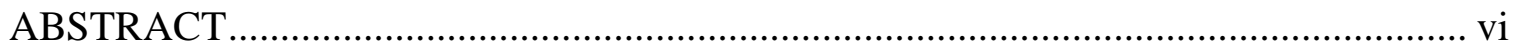

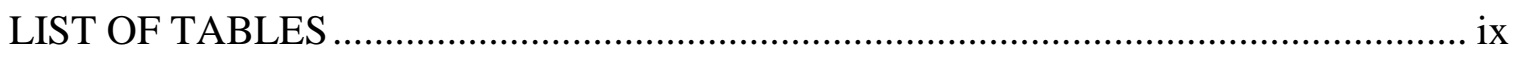

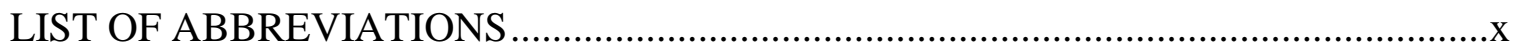

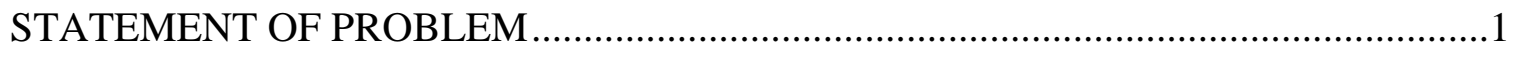

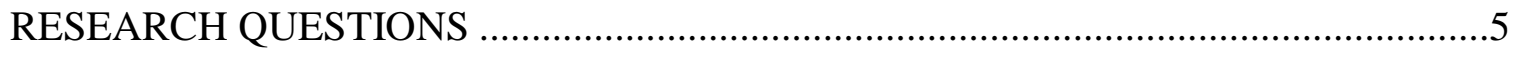

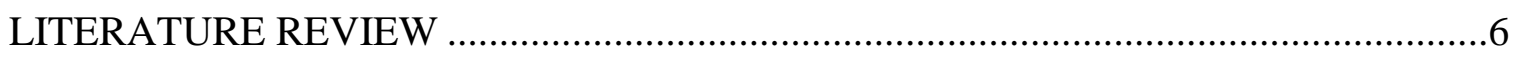

Purposes of Charter Schools ........................................................................6

Impact of Charter Schools ..............................................................................

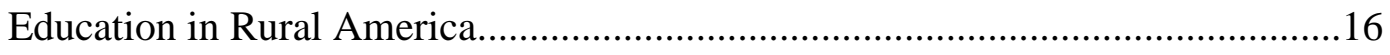

Rural Charter School Impact …………………….......................................19

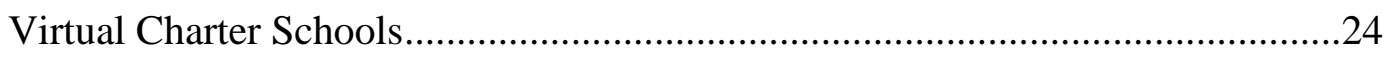

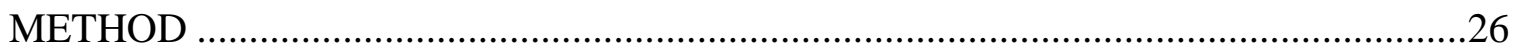

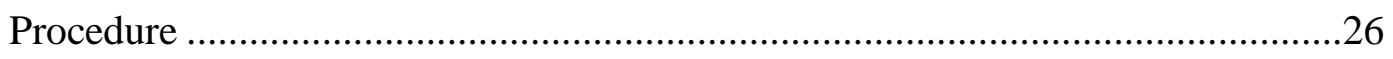

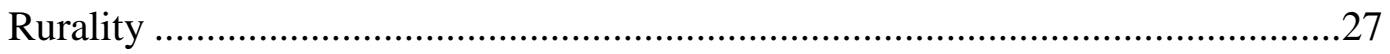

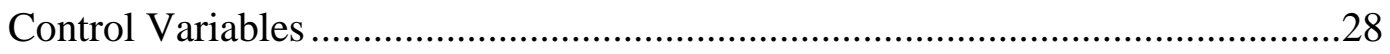

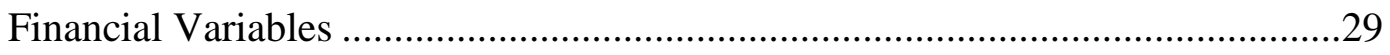

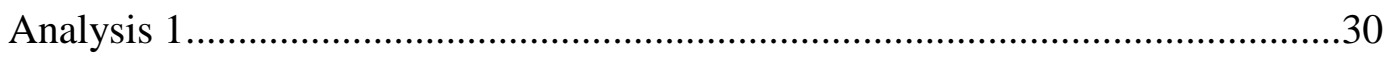




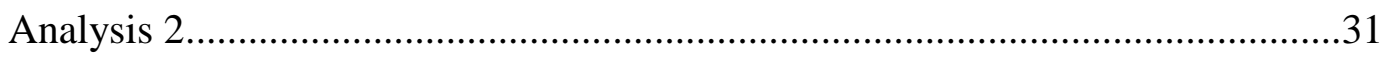

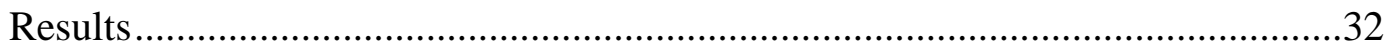

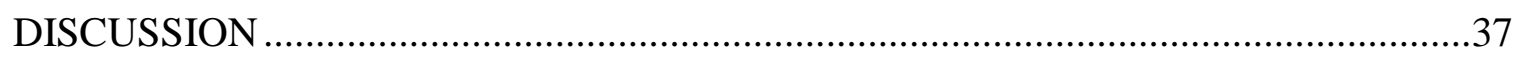

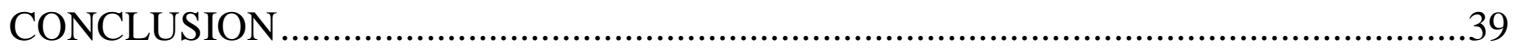

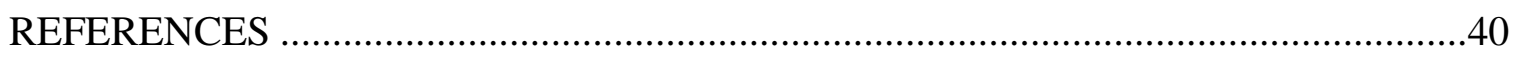




\section{LIST OF TABLES}

Table 1. Descriptive Statistics Model 1 Variables .................................................... 31

Table 2. Descriptive Statistics Model 2 Variables ................................................ 32

Table 3. Logistic Regression Results Analysis 1 …………………………........ 33

Table 4. $\quad$ Logistic Regression Results Analysis 2 ................................................ 35 


\section{LIST OF ABBREVIATIONS}

TPS Traditional Public School 


\section{STATEMENT OF PROBLEM}

School choice is currently a national high priority in the United States. In addition to traditional public schools, school choice includes students who choose to attend charter schools, private schools, magnet schools or are home-schooled. The Secretary of the United States Department of Education views charter schools and private schools as essential elements in creating educational freedom that can provide all students with the quality education they deserve (DeVos, 2019; Kaplan \& Owings, 2018; U.S. Department of Education, 2019). This focus presents a need to understand the school options available for students throughout the country (CREDO, 2013; Cohodes, 2018). Approximately $6 \%$ of all school-aged children in the United States attend a charter school, while $10 \%$ attend private schools and $3 \%$ are homeschooled (Redford, Battle, \& Bielick, 2017; U.S. Department of Education, 2018). This leaves a majority (81\%) of students in the traditional public-school system.

The comparatively low enrollment in alternative schooling options is not due to lack of interest (Brimley, Garfield, \& Verstegen, 2005; David, Hesla, \& Pendergrass, 2017; Mead, Mitchel, \& Rotherham, 2015). Charter schools and private schools often have waiting lists because they do not have the capacity to meet demand (Vergari, 2007). Charter schools specifically are often legally required to cap enrollment numbers, making it impossible to grow to meet demand (Timpane et al., 2001; Mead et al. 2015; Vergari, 2007). Interest is high because parents believe that schools of choice offer them more power over their child's education (Good \& Braden, 2014; May, 2006), improve their 
child's academic performance (Collins, 1999; Mead et al., 2015), and improve traditional public school (TPS) performance overall (Brimley et al., 2005; Cohodes, 2018).

School choice options vary in availability and popularity across different demographic and geographic segments of the populations (McCarthy, 2016). In urban areas, $36 \%$ of students attend a school other than a TPS compared to $18 \%$ of students in rural areas (Stuit \& Doan, 2012). In the U.S., only $25 \%$ of school-aged children live in rural areas; consequently, they are not represented well in national-level policies (Fishman, 2015; Mathis, 2003; Johnson \& Howley, 2015). School choice is commonly studied at a national level without making distinctions between, or accounting for, the different needs of urban and rural locations (Strange, 2011; Biddle \& Azano, 2016; Smarick, 2014). This generalization of data makes it difficult to understand the impact or relevance of school choice in rural areas (McCarthy, 2016; Biddle \& Azano, 2016). The importance and necessity of school choice being emphasized in the national dialogue makes the effort to expand rural-specific research necessary (Biddle \& Azano, 2016; Cohodes, 2018; Ladd \& Singleton, 2017).

In rural areas, school choice is often limited to charter schools or homeschooling (Cohodes, 2018; Fishman, 2015). Since charter schools are funded by public dollars and have limited required qualifications for creators, they are easier to create and more community accessible than private schools (Brimley et al., 2005; Good \& Braden, 2014). Data on homeschooling is not always available and represents so little of the general population so research on homeschooling is not always done. As a result, rural school choice research is mainly focused only on charter schools. As charter schools grow in popularity, it is important to note that of all charter school students in the U.S., only $15 \%$ 
live in rural areas. As previously stated, low enrollment is not always indicative of lack of interest (Brimley et al., 2005; David et al., 2017; Mead et al., 2015) and this is especially true in rural areas (Fishman, 2015; McCarthy, 2016).

Many parents in rural areas desire to make a choice for their child to have an education different from what the local TPS can provide, but the choice is not available (McCarthy, 2016; Bagley et al., 2001). States like Montana, South Dakota, and West Virginia have high populations of rural students but do not have laws allowing charter schools to be created (Stuit \& Doan, 2012). In some states that do have charter school laws, charter schools do not have enough financial, political, or community support to thrive or even be considered as an option (Fishman, 2015; Mead et al., 2015). However, there are charter schools in rural areas that thrive (Collins, 1999). The success of these schools is often attributed to the school connecting well with community needs or having strong community support (Collins, 1999; Mathis, 2003; Miller, Scanlan, \& Phillippo, 2017).

Communities play a large role in the success of both TPSs and charter schools, especially in rural areas (Johnson \& Howley, 2015; Stuit \& Doan, 2012). In many cases, community characteristics impact student performance as much as the school characteristics (Bodine et al., 2008; Reeves, 2012). The research presented in this study acts as a feasibility study of the potential for rural communities across the U.S. to create charter schools, given their financial characteristics. It also examines the impact of these financial demographics on a charter school's ability to remain open in a given rural area. These relationships will be compared with the influences of school characteristics that are commonly related to rural school success (Bodine et al., 2008). Financial characteristics 
were chosen over other social and political demographics because of the large role that funding plays in the ability to create a school, regardless of community support and opinion (Bryant Jr., 2010). Financial challenges are also the subject of most research regarding the success of any rural education (Arsen \& Ni, 2012; Cohodes, 2018; Schafft et al., 2014).Charter school research usually focuses on the resources rural communities lack in regard to the creation and persistence of charter schools (Fishman, 2015; Mead et al., 2015; Stuit \& Doan, 2012), however, this study chooses to focus on the financial circumstances of rural communities and if those circumstances improve the chances for charter school creation and persistence.

Feasibility studies are commonly used to understand the likelihood of an intervention to succeed in different environments (Arain, Campbell, Cooper, \& Lancaster, 2019; Bowen et al., 2009). Feasibility studies are necessary when an intervention, like a charter school, is being expanded to unique populations, such as rural areas (Arain et al., 2019). This study does not attempt to prove that charter schools are better or worse for rural communities; it instead focuses on determining if charters can exist in rural areas. 


\section{RESEARCH QUESTIONS}

What impact do the financial demographics (average income of the population, funding of public schools, and the prevalence of poverty) of a rural community have on the community's ability to create a charter school in the rural United States? Once a charter school has been established, what impact do the financial demographics of a rural community in the United States have on the community's ability to sustain that charter school for another year? 


\section{LITERATURE REVIEW}

Charter schools have been a part of the academic conversation since their creation in 1993 (Good \& Braden, 2014). Charter schools have existed for more than two decades and in that time, they have remained a controversial subject (Vergari, 2007). The following literature review examines both the benefits and disadvantages of charter schools to create an understanding of the controversy and the overall impact that charter schools could have in rural areas. This is done by first reviewing the purposes of early charter schools, their current functions, and the impact of charter schools on creating equity and improving student achievement. These topics are then addressed in a rural context, describing the merits and weaknesses of the presence of charter schools in rural communities. The financial and economic ramifications of charters in rural and non-rural areas is also discussed. This section also includes a brief overview of virtual charter schools and their role in rural areas and in this analysis.

\section{Purposes of Charter Schools}

Charter schools as they are known today started in Minnesota in 1993 (Brimley et. al., 2005; Cohodes, 2018). The school choice movement, however, started a few decades earlier with the creation of The Freedom Schools by civil rights groups in 1964 (Dingerson, Peterson, Walters, \& Miner, 2008; Forman Jr., 2004). These schools aimed to improve the academic performance of black children in ways that the TPS system did not (Dingerson et al., 2008; Forman Jr., 2004). The Freedom Schools originated as a summer school program and led to the "free school" movement that provided alternative 
education opportunities during the school year for the following decade (Forman Jr, 2004). These "free schools" focused less on the racial component of The Freedom Schools and more on the concept that schools were failing all children because of their bureaucratic entanglement (Dingerson et al., 2008; Forman Jr., 2004). These schools were ultimately organized as a radical reform from outside the school system rather than from within, in an effort to urge public schools to be more responsive and effective (Dingerson et al., 2008; Forman Jr., 2004).

The charter school movement today has similar purposes (Brimley et al., 2005). The main purpose for charter schools is to create competition for TPSs (Cohodes, 2018; Collins, 1999; DeVos, 2019; Good \& Braden, 2014; Kaplan \& Owings, 2018). When students choose to attend a charter school rather than a TPS, the TPS loses federal and state funding for those students (Cohodes, 2018; Darling-Hammond \& Montgomery, 2008; Kaplan \& Owings, 2018). By increasing the number of charter school options, education becomes a "business responsive to market forces of consumer choice" (Kaplan \& Ownings, 2018, p. 212). The idea is that as school options increase, all schools will be motivated to perform well and offer more to students to keep students and their corresponding funding (Dingerson et al., 2008). This competition is ultimately intended to improve overall school quality (Good \& Braden, 2014). Charter school critics often argue that education is a public good and that funds used for charter schools would be more effectively used for improvement of currently operating schools, allowing all students to receive the benefits, not just those that attend charters (Bryant, 2010; Kaplan \& Ownings, 2018). Likewise, critics believe the existence of multiple educational options 
creates more opportunities for students to receive an inequitable and inferior education (Kaplan \& Ownings, 2018).

An important motive of charter schools is to create schools that have more autonomy than TPSs, allowing for administrators, parents, and teachers to have more power (Fishman, 2015; Forman Jr., 2004; Good \& Braden, 2014). Administrators have more managerial freedom and are not required to follow all state regulations such as attendance boundaries, class sizes, and hours of operation (Fishman, 2015). Teachers are able to have more control over their pedagogical and curricular choices (Fishman, 2015). Charter schools allow parents to feel they have control over their child's education (Collins, 1999; Dingerson et al., 2008; Good \& Braden, 2014). This feeling of power stems from not only the ability to choose an alternate school but, once working with that school, parents feel they have more voice in school decisions, including curriculum (Good \& Braden, 2014). This idea of this power makes some parents more likely to invest in the idea of creating a charter school in their community, especially when they see their current TPS as a failure (Collins, 1999). As a result, charter schools tend to be located "in communities where parents tend to be more motivated and better informed" (Ni, 2009).

The charter school movement also aims to produce educational innovation in curriculum, administration and governance, teacher salaries, training, support and evaluation (Mead et al., 2015). These innovations are key to making the charter school experience different from the TPS experience (Good \& Braden, 2014). The most successful innovative ideas adapt educational experiences to meet the needs of students and the community (Dingerson et al., 2008; Good \& Braden, 2014), provide support and 
feedback to teachers, and offer data-driven instruction (Cohodes, 2018). Charter proponents feel the TPS system can be initially resistant to change and too large to foster innovation and charter schools are seen as the solution to those problems (Good \& Braden, 2014). Although innovation is a goal for charter schools specifically, innovative ideas created and tested within the schools can only be effective in improving educational quality and equity throughout the community if they are also implemented in TPSs and if the student demographics of charters are similar to those TPSs (Darling-Hammond \& Montgomery, 2008; Mead et al., 2015).

The capability of charter schools to fulfill these purposes varies (Kaplan \& Owings, 2018). In some communities, such as New Orleans, successful charter schools have completely replaced TPSs (CREDO, 2013; Dingerson et al., 2008). In some instances, though, charter schools struggle to maintain quality and fail (Dingerson et al., 2008). These differences can be attributed to the market aspect of the charter school movement (Kaplan \& Owings, 2018). If the purpose of charter schools is to create autonomy and competition then it is impossible to create a consistent system of charter schools that are guaranteed to be successful at fulfilling the purposes of charter schools (Dingerson et al., 2008; Kaplan \& Owings, 2018). Charter school advocates see both the persistence of successful schools and the closure of failing schools as an example of the importance of having a competitive market within education by constantly eliminating what does not work and focusing on improving what does work (May, 2006; Mead et al., 2015). However, charter school critics see the constant opening and closing of schools as a waste of the public funds poured into them—funds that could be used to improve existing schools (Bryant Jr., 2010; Good \& Braden, 2014; Kaplan \& Owings, 2018). 


\section{Impact of Charter Schools}

Increased competition, innovation, and stakeholder autonomy are the purposes of charter schools, but the goal of charter schools is to create schools that provide higher quality and more equitable academic outcomes than TPSs (David et al., 2017; May, 2006; Veragari, 2007). The ability of charter schools, including their financial capacity, to accomplish this goal is discussed in this section.

Charter schools currently serve 3.2 million students in about 7000 schools across the United States (National Alliance for Public Charter Schools, 2019). This is only about $6 \%$ of all public-school students (U.S. Department of Education, 2018), but the number of charter school students has been steadily increasing for ten years (Mead et al., 2015; National Alliance for Public Charter Schools, 2019). This consistent growth of charter enrollment has been accompanied by years of research regarding charter school performance (Cohodes, 2018; CREDO, 2013; Good \& Braden, 2014).

Charter school performance improves each year (CREDO, 2013; Mead et al., 2015). CREDO measures charter school performance by standardizing English language arts and math test scores across states to measure yearly growth (CREDO, 2013). Charter student performance is measured against performance of similar peers in TPSs and students in charters and each year more charter students perform better than the TPS peers (CREDO, 2013). Despite this improvement, charter schools as a whole perform similarly to TPSs (Cohodes, 2018; May, 2006). This is because achievement in individual charter schools varies greatly by demographics, charter operators, and location (CREDO, 2013; May, 2006). Minority and low-performing students tend to benefit from attending charter schools (Mead et al., 2015). In successful charters, students in poverty, English 
Language Learners (ELL), African American students, African American students in poverty, Hispanic students in poverty, and Hispanic ELL students all see increased test performance in both reading and math compared to their TPS counterparts (CREDO, 2013; Mead et al., 2015). The improvement seen in these minority groups provides evidence of the ability of charter schools to provide a more equitable education (CREDO, 2013). Group improvement among low-income students and students of color is especially relevant in "no excuses" charter schools (Cohodes, 2018; Epple, Romano, \& Zimmer, 2016).

Charter schools that identify as "no excuses" are usually operated by non-profit charter management organizations (CMOs); approximately $24 \%$ of charter schools are operated by CMOs, $61 \%$ are freestanding charters, and $15 \%$ are operated by for-profit institutions (Mead et al., 2015). Freestanding charters and CMOs usually perform similarly or better than TPSs, whereas for-profit charter schools tend to perform worse (Epple et al., 2016; Mead et al., 2015). Most CMOs are located in urban areas, and highperforming CMOs either take a traditional approach to curriculum or adopt a "no excuses" curriculum (Cohodes, 2018; Mead et al., 2015). "No excuses" schools have high expectations for students to perform well academically and behaviorally, offer tutoring, have longer school days and school years, and provide teachers with consistent support and feedback (Cohodes, 2018). "No excuses" charter schools are usually successful and replicable, but replication usually only occurs in urban areas (Cohodes, 2018; Mead et al., 2015).

An example of a "no excuses" CMO is the Knowledge is Power Program (KIPP) organization. Over 200 KIPP schools serve 31 urban regions and one rural region across 
the United States (www.kipp.org, 2019). The KIPP organization is one of the few "no excuses" CMOs with rural schools. In 2002, KIPP schools were introduced in rural Arkansas (Rose, Maranto, \& Ritter, 2017). These schools have been successful in improving test scores; however, there has been no further rural expansion of KIPP schools (Fishman, 2015; Rose et al., 2017). The potential of KIPP success in other rural areas is unknown, but due to the large amount of resources needed to begin a "no excuses" charter school, rural creation or replication appears unlikely (Cohodes, 2018; Rose et al., 2017).

In addition to being home to most "no excuses" schools, urban areas have more charter schools than rural areas in general, representing $57 \%$ of total charter school enrollment (May, 2006; National Alliance of Public Charter Schools, 2019). Comparatively, urban areas educate only $30 \%$ of all public-school aged students in the United States (McFarland et al., 2018). Areas with high proportions of students in charter schools, such as New Orleans and Detroit, are all highly urban and tend to serve a higher percentage of low-income students and non-white students compared to their TPS counterparts (Mead et al., 2015; Epple et al., 2016). Low-income parents and parents of color in urban areas often see their own TPS as failing (Bagley et al., 2001) and are drawn to charter schools, viewing them as safer than local TPSs and as providing higher quality education opportunities for their children (Dingerson et al., 2008; Epple et al., 2016).

The demand from parents for charter schools in urban areas has increased the supply, making urban charter schools overrepresented in the school choice discussion (Epple et al., 2016; Fishman, 2015). This overrepresentation makes it difficult to 
generalize research findings, meaning that very little is known about charter school impact on rural areas (Biddle \& Azano, 2016; Fishman, 2015). The overrepresentation of urban charter schools can also influence policy (Fishman, 2015). If policies are based on the resources and performance of established urban charter schools, rural areas might not have the resources, such as facilities and teacher supply, to be created or the opportunity to grow and improve (Dingerson et al., 2008; Fishman, 2015; Ladd \& Singleton, 2017; McCarthy, 2016).

An exact list of elements that could cause individual charter schools to be successful in academic performance or equitable education is difficult to identify (Mead et al., 2015). Amongst successful charter schools there are a few common elements that could explain success (Epple et al., 2016; Mead et al., 2015). These include schools with alternative governance, large amounts of additional financial and physical resources, community support, highly qualified teachers and teacher support, and data driven instruction (Epple et al., 2016; Mead et al., 2015). Research also finds that these traits are also found in successful TPSs, however, charter school advocates argue that it is easier to provide these qualities in more autonomous charter schools (Cohodes, 2018).

Critics argue that charter schools cannot be successful in providing equitable and quality education (Kaplan \& Owings, 2018). Charter schools by nature educate a different kind of student than in a TPS because charter schools only educate students who have parents that put forward the effort to make school choice decisions (Cohodes, 2018). These students usually already have a greater chance for success than students with parents that are not making efforts to change the quality of their child's education (Cohodes, 2018; Ni, 2009). 
In some cases, offering an alternative schooling option can increase segregation (Dingerson et al., 2008; Ladd \& Singleton, 2017; May, 2006). This segregation is seen in urban areas as students of color choose to attend charter schools that are often marketed toward their needs, such as programs with longer school hours to provide more time in safer environments and less time home alone while parents work (Ladd \& Singleton, 2017; Mead et al., 2015). In all areas, but especially in suburban areas, charter schools exacerbate "white flight," often leaving behind minority students in poorly funded schools while white students receive a better education (Dingerson et al., 2008; McCarthy, 2016). In some areas, the increase of segregation is not as dramatic, but there is still a different demographic distribution of students compared to TPS in the area (Cohodes, 2018; Mead et al., 2015).

Charter schools everywhere struggle specifically with serving students with disabilities (Mead et al., 2015). Though required to educate all students, hiring additional staff to fulfill learning plans and student needs is difficult for charters and, as a result, they often have much lower special education enrollment than their TPS counterparts (Mead et al., 2015). The ability of a charter school to provide a quality equitable education for all students leads to a debate of whether it is ethical to distribute funds to a school that does not serve all students equally (Dingerson et al., 2008; Good \& Braden, 2014; Vergari, 2007).

The financial impact of charter schools, much like academic achievement, varies by location and by charter operator (Cohodes, 2018; May, 2006). Charter schools are financed by public dollars but are subject to different funding formulas than TPSs and often receive less money from their state per student than TPSs (Epple et al., 2016; Mead 
et al., 2015). Regardless of this difference, on average, charter schools end up with a similar amount of funds compared to TPSs because they are able to collect money from non-state sources while remaining a public school (Bodine et al., 2008; Epple et al., 2016; Merry \& New, 2017). CMOs are more likely to receive large amounts of outside funding, giving them more financial freedom to acquire the needed resources to provide a highquality education (Bodine et al., 2008; Fishman, 2015; Kaplan \& Owings, 2018). Charter schools advocates often feel charters need more money than their TPS counterparts because they have large start-up costs and are required to find and fund all facilities and associated fees (Epple et al., 2016; Farmer, Baber, \& Poulos, 2017; Vergari, 2007). However, it is important to note that charter schools often have access to grants designed specifically for charter schools and are still eligible for the federal grants that are for all public schools, giving them more opportunities to raise funds, despite only educating $6 \%$ of the population (Bryant Jr., 2010).

In addition, as charter schools grow, their TPS counterparts experience financial strain (Cohodes, 2018; May, 2006; Vergari, 2007). Most state funding formulas are perpupil based, meaning that money follows students as they move from school to school (Cohodes, 2018; Ridley \& Terrier, 2018; Vergari, 2007). Losing even a few students can make a difference; funding decreases while most large expenditures, such as electricity, bussing, teacher need and salaries, remain the same (Kaplan \& Owings, 2018; Ridley \& Terrier, 2018; Schafft et al., 2014). In extreme cases, some TPSs eventually close because they can no longer operate financially (Cohodes, 2018; Epple et al., 2016; Kaplan \& Owings, 2018). Charter school advocates believe that this is a benefit of having a marketbased education system and that as schools lose students, schools should work to improve 
the education they provide to draw students (Collins, 1999; Good \& Braden, 2014). However, by losing students and subsequent funding, TPSs are unable to make the improvements necessary to outperform competition (May, 2006; Ridley \& Terrier, 2018). Test scores are impacted as schools direct increasingly limited funding toward administration and facilities to keep the school operating, and divert from student needs (Cohodes, 2018; Ni, 2009; May, 2006; Ridley \& Terrier, 2018).

Fiscal struggles are especially relevant for both local TPSs and charter schools in rural areas, where there are fewer students to share between TPSs and charter schools (Ladd \& Singleton, 2017; Schafft et al., 2014; Strange, 2011). Rural TPSs are more likely to struggle with the loss of a few students from each grade and are also more likely to experience closures when losing a small number of students (Epple et al., 2016; Ladd \& Singleton, 2017). Rural charter schools, including CMOs, find it challenging to raise enough funds to create quality schools (Fishman, 2015). The following section discusses further the challenges faced in rural education.

\section{Education in Rural America}

In the United States, the definition of rural has become culturally relative, usually meaning "any place smaller than where I live" (Strange, 2011, p. 9). The National Center for Education Statistics (NCES) uses U.S. Census Bureau definitions as the basis for rural classification of school districts (NCES, n.d.). The definition of rural by NCES is any area that is five miles or more from an urbanized area or an area that is two and a half miles or more from an urban cluster (NCES, n.d.). According to the U.S. Census, an urbanized area is an area with 50,000 or more people (Ratcliffe, Burd, Holder, \& Fields, 2016). Urban clusters are any areas that have between 2,500 and 50,000 people but only 
if they have a population density of 1,000 people per square mile (Ratcliffe et al., 2016). The NCES divides rural areas into three categories: fringe, distant, and remote (NCES, n.d.). Based on these definitions, urban schools educate $30 \%$ and rural schools educate $25 \%$ of all school-aged children in the U.S., in more than a third of all U.S. schools (Bagley et al., 2001; Mead et al., 2015). Students in fringe communities benefit from being closer to urban areas, while remote areas educationally struggle more, but rural school problems impact every level of rurality (Biddle \& Azano, 2016; Stuit \& Doan, 2012).

Students in rural schools often have fewer academic opportunities compared to their urban counterparts (Miller et al., 2017; Reeves, 2012). This lack of opportunities is often attributed to a teacher shortage (Mathis, 2013; Reeves, 2012). When rural schools are not able to find teachers, hiring qualified teachers becomes less of a priority, and as a result, students receive a lower quality education (Dingerson et al., 2008). In addition to teacher shortages, low test scores have also been attributed to inadequate funding, poor community resources, and state curriculum that does not account for the specific needs of rural students (Fishman, 2015; Reeves, 2012; Schafft \& Jackson, 2010).

Many students in rural schools are not adequately prepared for life after high school graduation because when schools focus on college preparation, career and technical training suffers (Fishman, 2015; Stuit \& Doan, 2012). Career and technical education (CTE) courses have become less common in rural schools (Fishman, 2015). This is usually due to CTE funds being reallocated to college-preparatory classes, not a lack of interest in CTE from students (Fishman, 2015; Stuit \& Doan, 2012; Reeves, 2012). Fishman (2015) states that "an education system custom made for rural 
communities would ensure that those who wish to stay in their community...have access to relevant career education while they are in high school" (p. 5). While national and state level policies push college-for-everyone models, the needs of rural communities are not met (Mathis, 2003).

A major rural TPS challenge is obtaining adequate funding (Biddle \& Azano, 2016; Mathis, 2003). Policymakers do not always consider the impact that state and national policies have on rural schools (Biddle \& Azano, 2016; Strange, 2011). Urban areas usually have a much higher tax base for education and more opportunities to receive local supplemental funding, so budget cuts at the national level do not have the same impact as they do in rural areas (Biddle \& Azano, 2016; Mathis, 2003). As a result, rural schools have significantly less money to spend per-pupil and struggle to provide students with the same level of education as other areas (Fishman, 2015; Mathis, 2003).

In general, rural areas are experiencing population loss (Fishman, 2015; Sherman \& Sage, 2011; Strange, 2011). As a result, many rural schools are closing (Kaplan \& Owings, 2018; Strange, 2011). This negatively impacts the community because students must attend schools that are further away, increasing travel time for parents, increasing spending on bussing, and decreasing community focus (Howley, Johnson, \& Petrie, 2011; Strange, 2011). School districts are often the largest employers for the community, so when a school is forced to close, many community members are left without a job (Biddle \& Azano, 2016; Howley, Howley, Hendrickson, Belcher, \& Howley, 2012; Sherman \& Sage, 2011). For these reasons, many rural areas are resistant to adding charter schools in fear that by spreading resources between schools, TPSs and charter 
schools will both struggle, and all schools will eventually be forced to close (Fishman, 2015; Smarick, 2014; Strange, 2011).

Rural communities are often anchored in local schools (Irvin et al., 2011; Miller et al., 2017). Rural schools act as social gathering places for not just students, but all community members (Irvin et al., 2011; Mathis, 2003; Sherman \& Sage, 2011). As a result, many community members view schools as sources of community strength and unification (Fishman, 2015; Bingler et al., 2002; Sherman \& Sage, 2011). Community support of schools often leads to more funding, positive parent involvement, and better student outcomes (Irvin et al., 2011; Mathis, 2003; Miller et al., 2017). Communities benefit from these relationships, as schools work to fill community needs, such as adding more CTE classes in high schools, or work to improve social problems such as poverty by offering programs and assistance to high-need students (Fishman, 2015; Mathis, 2003). Overall, the key to any successful rural school is to focus on community needs and resources (Collins, 1999; Fishman, 2015; Johnson \& Howley, 2015).

\section{Rural Charter School Impact}

Charter school advocates believe introducing more charter schools to rural areas solves many rural education problems while also enhancing community values and filling community needs (Collins, 1999; Fishman, 2015). The autonomy of charter schools allows them to better use community resources and focus on community needs without having to adhere to urban-centric laws (Collins, 1999; Fishman, 2015; Stuit \& Doan, 2012). This includes the ability to add courses based on student demand and, in some cases, implement a school-wide focus that connects students back to their community (Collins, 1999; Fishman, 2015). For example, agricultural schools that, in addition to 
rigorous coursework, provide students with apprenticeships throughout the community to get practical experience (Fishman, 2015; Stuit \& Doan, 2012).

Charter schools can sometimes be sustained in areas of forced TPS closure because they are not held to the same standards as a TPS (Collins, 1999; Fishman, 2015). For example, charters do not have to meet class size requirements and do not have to set attendance boundaries for potential students (Fishman, 2015). As a result, advocates often view a closure of a rural TPS as an opportunity to open a local charter school and provide communities with the social and economic benefits of having a school (Collins, 1999; Fishman, 2015; Stuit \& Doan, 2012). In areas where rural TPSs still exist, charter schools can partner with TPS districts to share the funding burden of common overhead costs, including legal services, financial analysis and management, technology training, and teacher training (Fishman, 2015). These partnerships allow for both charter schools and TPSs to have more funding to devote to student learning (Fishman, 2015).

Charter schools may be able to have a positive social impact on rural communities, but the academic impact of rural charter schools is mostly unclear (Fishman, 2015). The Center for Research on Education Outcomes (CREDO) has done extensive research on the academic achievement of charter schools, including the impact of rural charter schools on performance (CREDO, 2019). CREDO has not done research in every state regarding rural charter school performance. Drawing from the states that have been studied, CREDO found that rural charter schools in California, Ohio, and Louisiana perform significantly worse than their TPS counterparts (CREDO, 2013a, 2014, 2014a). However, in Texas, rural charter schools performed similarly to their TPS counterparts (CREDO, 2017) and in Idaho, rural charter schools perform much better 
than their TPS counterparts (CREDO, 2019). These rural outcomes were often not congruent with the impact of urban schools in each respective state (CREDO, 2013a, 2014, 2014a, 2017, 2019). These differences could potentially be explained by the community environment of rural charter schools (Bodine et al., 2008; Reeves, 2012; Vergari, 2007)

\section{Rural Charter School Challenges}

There is a general understanding of challenges faced by charter schools in rural communities (Mead et al., 2015; Stuit \& Doan, 2012). These challenges seem to be ubiquitous, despite the differences of rural areas across the country (Darling-Hammond \& Montgomery, 2008; Vergari, 2007). These challenges fall into four categories: lack of community support, lack of political support, lack of financial capital, and lack of human capital (Fishman, 2015; Mead et al., 2015).

As previously discussed, TPSs and charter schools both benefit from community support (Irvin et al., 2011; Mathis, 2003; Miller et al., 2017). Most parents in rural areas believe their local TPS is satisfactory and do not see a need to create a charter school, which makes it difficult to attract enrollment at newly established charter schools (Fishman, 2015; Mead et al., 2015). Community support involves more than parent demand; community members play a role in fundraising efforts, recruiting educators, and improving student achievement (Collins, 1999; Reeves, 2012). In many ways, adequate community support has the potential to ameliorate the other challenges faced by rural charter schools (Collins, 1999; Stuit \& Doan, 2012).

The lack of political support for rural charter schools occurs at the local and the state level (Mead et al., 2015; Miller et al., 2017). Political opposition at the state level is 
a complex problem (Mead et al., 2015). Charter laws are created at the state-level, and as a result, some states with high rural populations do not allow for charter school creation, such as West Virginia and Montana (Stuit \& Doan, 2012). In states with favorable charter laws, state laws tend to be urban-centric, meaning they may not account for the limited resources in rural areas (Fishman, 2015; McCarthy, 2016). Charter schools may also face political opposition at the local level (Timpane et al., 2001; Miller et al., 2017). Charter schools and school choice in general are associated with political stance; allowing a charter school in a rural area could be viewed as a political statement of the creators and board members, making the possibility too controversial to be feasible (Timpane et al., 2001; Mead et al., 2015).

Rural charter school financial struggles, such as struggles to obtain funding and financial capital, were briefly discussed in an earlier section. The struggle to obtain sufficient funding has specific repercussions (Stuit \& Doan, 2012). Rural charter schools often must build their own facilities or invest their already limited budget in renovation because of limited available structures in rural areas (Collins, 1999; Mathis, 2003; Mead et al., 2015; Stuit \& Doan, 2012). Schools in rural areas often must invest more money in transportation than in urban areas, as urban students can use local public transportation or walk to travel to school, while rural students often rely on school-provided buses (Mead et al., 2015; Stuit \& Doan, 2012). These, in addition to other high start-up costs such as purchasing desks and computers, make it difficult for rural charter schools to use funding to provide an innovative and quality education alternative to local TPSs (Fishman, 2015; Timpane et al., 2001; Stuit \& Doan, 2012). 
The human capital, often related to financial capital, available to rural charter schools also impacts their ability to provide an equitable and quality education (Mead et al., 2015). Rural communities are facing economic stagnation (Fishman, 2015). Many rural youth leave the community after high school to pursue post-secondary education and often do not return (Sherman \& Sage, 2011). This "rural brain drain" often leaves rural areas with a population without the education needed to create and work within charter schools (Mead et al., 2015; Sherman \& Sage, 2011). Charter school creators, or operators, who do not have educational or administrative experience, or financial and legal knowledge have a much higher chance of failing (Good \& Braden, 2014). If a previously successful charter school wants to expand in rural areas, a native qualified operator is preferred; if there is not one in the area, the program has to spend funds on relocating a qualified individual (Collins, 1999; Mead et al., 2015; Miller et al., 2017).

Qualified operators are the first of the many people needed to make a charter school operate successfully and meet its intended goals (Mead et al., 2015). Charter schools need committed and intelligent administrators as well (Mead et al., 2015; Stuit \& Doan, 2012). This is especially true in rural areas, where administrators take on roles often filled by additional staff in urban areas, such as reporting statistics to the state, acquiring funds through grant writing, and building community relationships (Fishman, 2015). Like their TPS counterparts, charter schools are required to have a school board, and finding willing and competent charter board members can be a challenge in rural areas (Stuit \& Doan, 2012).

Much like rural TPSs, rural charter schools struggle to fill teaching positions (Dingerson et al., 2008; Mathis, 2003). As a result, rural charter schools, in states where 
the law allows, hire teachers that are not certified, risking the quality of education they are able to provide (Dingerson et al., 2008). Many rural charters are not able to offer specialized classes, such as art, music, or foreign languages, simply because they are unable to fill the positions (Stuit \& Doan, 2012). Finding teachers and support staff for special education programs can also be difficult in rural charter schools, preventing their ability to provide an equitable education (Mead et al., 2015; Stuit \& Doan, 2012).

This study attempts to determine the feasibility of a community to create and sustain charter schools based on the financial characteristics (or capital) of that community. Understanding the impact of this relationship could potentially help individual communities understand their ability to create a charter school (Bodine et al., 2008; Reeves, 2012). Despite criticism surrounding charter schools, many rural areas have benefited from creating a charter school because of the school's ability to individualize learning to unique rural challenges (Fishman, 2015). This research adds to the national conversation of school choice by determining the accessibility and plausibility of U.S. students across the country, including those in rural areas, to have increased access to school choice options.

\section{Virtual Charter Schools}

Virtual charter schools are marketed to rural areas as a solution to lack of funding, human capital, and other resources, in TPSs and charters alike (Pazouh, Lake, \& Miller, 2015). Virtual charter schools are defined as

"schools which provide the majority of classes (everything except PE, band, or a similar elective) to full-time students through a computer via the internet. Lessons may by synchronous or asynchronous. Lessons may consist of 
videos, live chat, bulletin boards, or any other common means of electronic communication. But the primary delivery method must be online." (CREDO, 2015, p. 4)

Online charter schools are present in 23 of the 44 chartering jurisdictions ( 43 states and D.C.), educating somewhere between 180,000 and 200,000 students (Pazouh et al., 2015; Smith \& Westapher, 2017). Only six of these 23 jurisdictions require virtual charter schools to have some sort of physical presence. However, this physical presence does not need to adhere to any standardized purpose. Virtual charter schools could create a physical place for teachers to record lessons, receive feedback and support, or meet and discuss curriculum that allows for a more quality education (Smith \& Westapher, 2017). In most cases, the physical presence of virtual charter schools is most often merely administrative offices (Smith \& Westapher, 2017).

Despite the convenience of online learning, the quality of the learning is poor (CREDO, 2015; Smith \& Westapher, 2017). Five different reliable research institutions studied performance of students in virtual charter schools and all found that students enrolled in virtual charter schools perform significantly worse academically than students in brick-and-mortar schools, both charter and TPSs (Smith \& Westapher, 2017).

Virtual charter school data will not be included in the analysis conducted in this paper, regardless of their relevance in rural areas. The basis of this paper is to understand the ability of rural communities to create and sustain physical charter schools. As virtual charter schools impact more than one community and are often not created in rural communities, they do not apply to this analysis. 


\section{METHOD}

Two logistic regression models were created to answer the two research questions. Logistic regression was chosen because it allows for the analysis of a categorical output variable and continuous predictor variables. The first model focuses on the impact of financial demographics in the creation of a charter school in the rural United States. The second model focuses on the impact of financial demographics in the persistence of charter schools in the rural United States while accounting for additional characteristics of charter schools.

\section{Procedure}

Data for these models is publicly available from the National Center of Education Statistics (NCES). The NCES conducts the Common Core of Data survey each year. This survey collects enrollment numbers as well as financial and general demographic information from every school in the United States. The NCES also compiles a dataset called Education Demographic and Geographic Estimates (EDGE). This dataset consists of data from the U.S. Census Bureau's American Community Survey about communitylevel demographics that NCES then assigns to their corresponding school districts. This analysis will use data from the 2015/16 academic school year, the most recent year publicly available for both datasets. By nature of doing a national-level analysis with publicly available data, not every desired variable for analysis was available for the models. For example, poor student performance in a TPS is often an indicator in the demand for a charter school in a community (Cohodes, 2018; Kaplan \& Owings, 2018; 
$\mathrm{Ni}, 2009)$. However, there is not a standardized measure of student performance across all schools in the United States, leading to the decision to omit this variable from the models, despite its potential impact.

\section{Rurality}

The rural status of a community is based on the rural definitions created by NCES using definitions from the U.S. Census. The NCES has three different categories for rural areas: "Rural - Fringe," "Rural - Distant," and "Rural - Remote." As defined by NCES, "Rural - Fringe" areas are territories classified as rural that are closest to urban areas (5 miles or less) or urban clusters (2.5 miles or less). "Distant" areas are 5-25 miles away from urban areas (2.5-10 for urban clusters) and "Remote" areas are more than 25 miles and 10 miles away from urban areas and clusters, respectively.

In Analysis 1, 46 total rural charter schools were created in the 2015/16 school year. Twenty-seven $(58.7 \%)$ of the schools were in Rural-Fringe areas, 11 (23.9\%) in Rural-Distant, and 8 (17.4\%) were located in Rural-Remote areas. In Analysis 2, 682 rural charter schools were operating in the 2015/16 school year that also existed in the previous year. These continuing charter schools were located mostly in Rural-Fringe areas (399 (58.6\%)), $179(26.2 \%)$ were in Rural-Distant, and 103 (15.1\%) were in RuralRemote areas. In each model, the three categories were combined to represent general rural areas throughout the United States.

Rural areas with public schools in states that do not have laws that allow for the creation of charter schools are excluded from this dataset as they may have the conditions that allow for charter school creation but cannot legally do so. These states are Alabama, Montana, Nebraska, North Dakota, South Dakota, Vermont, and West Virginia. 


\section{Control Variables}

Diversity of the community is used as a demographic predictor in both models.

Diversity of the charter school is used as a school-specific predictor in Model 2. Diversity was chosen as a variable because in urban areas, minority groups tend to benefit from attending charter schools more than their white peers and perform better in charter schools than their minority peers in TPS (Cohodes, 2018; Mead et. al, 2015). Due to this significant impact, it is important to control for the influence of minority groups on schools of choice in rural areas as part of the analysis. In each model, "Diversity of a Community" is a reverse indicator, calculated as the percentage of people who identify as "white." In Analysis 2, "Diversity of Charter School" is similar, calculated as the percent of students in the school who identify as "white." The lower the scores for these variables, the higher the percentage or count of minority groups in the community or school.

Enrollment is also used as a demographic predictor in both models. Declining enrollments in a local TPS may have caused a school closure in previous years leading to longer commutes to larger areas for schooling and creating a demand for a school of choice in the area. Alternately, low enrollments in a TPS may lower the demand for a charter school because there are not enough children to divide between two schools (Mathis, 2003; Smarick, 2014; Strange, 2011).

The average education of a community is considered a demographic and therefore, control, predictor in both models. Charter schools need teachers, administrators, and other staff members that require a certain level of education. Communities with larger populations of those with college degrees could be more likely 
to open a charter school because of the increased hiring pool (Stuit \& Doan, 2012).

Parents with higher levels of education are also more likely to be involved in their child's schooling and would search out ways to improve it; and they might determine that creating a charter school would support that aim (Ni, 2009). In each model, the "Average Population Education" variable is the percentage of the population with at least a bachelor's degrees or more.

Analysis 2 uses three school-specific predictors. The first is the diversity of the school, measured by the metric previously mentioned. The second is the highest gradelevel served by the charter school and the final is the lowest grade-level served by the charter school. High schools are more costly to operate and require more staff than an elementary schools (Bodine et al., 2008). This could influence the ability of a charter school to sustain itself once created. The "Lowest Grade" and "Highest Grade Served by Charter" variables are self-explanatory.

\section{Financial Variables}

Income is used as a financial predictor in all models. The "Income" variable represents the area median income (AMI) for each community. In past studies, AMI was found to have an impact on the financial support available to charter schools (Bodine et. al, 2008). Income can also influence the local tax base, which is a significant portion of school funding (Bryant Jr., 2010; Johnson \& Howley, 2015).

School funding is another financial predictor in all models. Funding available to a TPS can influence student performance and parent satisfaction with the school (Cohodes, 2018; Kaplan \& Owings, 2018). A decrease in these could increase the demand for a charter school (Kaplan \& Owings, 2018; Ni, 2009). The funding available to a TPS can 
also serve as an estimate for the funding available to a charter school. Charters receive less public funding than their TPS counterparts, which impacts the potential of a charter school in the community (Mead et al., 2015; Stuit \& Doan, 2012). In each model, the "Funding" variable is the total dollar amount received by each school in the dataset. Poverty is the final financial variable used in each model. Charter schools are often created in urban areas as a response to poor TPS performance in high poverty communities (Dingerson et al., 2008; Ladd \& Singleton, 2017; May, 2006). This pattern could also be possible in rural areas as well. The "Poverty" variable is the percentage of families whose income in the past year was below the poverty level in each community.

\section{Analysis 1}

To understand the potential effect of financial demographic characteristics on charter school creation, this dataset consisted of all rural communities in the United States that contain public school districts and allow for the creation of charter schools. This allowed for a comparison of the financial demographics (average income of the population, funding of public schools, and the prevalence of poverty) of the communities that did not create a charter school and the communities that did for the given year. The predictive measures in this model are from the 2014/15 school year. The outcome, creating a charter school, is a variable created using data from 2015/16 school year. Table 1 summarizes these variables.

The first logistic regression includes the community demographic variables that are often used in charter school research. After the first regression, the financial demographics are added to the original model to identify their impact on the statistical 
significance of relationships found between financial demographics and charter school creation.

Table 1. Descriptive Statistics Model 1 Variables

\begin{tabular}{lllll}
\hline Variable & Mean & SD & Min & Max \\
\hline Average Population Income & $\$ 71,837$ & $\$ 25,856$ & $\$ 13,117$ & $\$ 418,374$ \\
Public School Funding & $\$ 74,300,000$ & $\$ 331,000,00$ & $\$ 18,000$ & $\$ 27,400,000,00$ \\
& & 0 & & 0 \\
Poverty & $10.36 \%$ & $6.65 \%$ & $0 \%$ & $100 \%$ \\
$\begin{array}{l}\text { Average Population } \\
\text { Education }\end{array}$ & $22.8 \%$ & $12.37 \%$ & $0 \%$ & $100 \%$ \\
$\begin{array}{l}\text { Ethnic Diversity of } \\
\text { Community }\end{array}$ & $77.92 \%$ & $21.76 \%$ & $0 \%$ & $100 \%$ \\
Average Enrollment & 6,561 & $24,727.35$ & 1 & 13,872 \\
\hline
\end{tabular}

Observations: ---

Data drawn from 2015/16 NCES CCD and EDGE datasets and the US Census

\section{Analysis 2}

To understand the ability of a rural community to sustain a charter school that has already been created, the dataset contained only communities that have a charter school in $2015 / 16$ as well as communities that had a charter school in the previous year that subsequentially closed. The financial demographics of these communities are compared with each other as well as with three school-specific predictors. The ability for charter schools to remain open could be attributed to community support but also could be attributed to the strength of the school itself. These variables are summarized in Table 2 . 
Table 2. Descriptive Statistics Model 2 Variables

\begin{tabular}{|c|c|c|c|c|}
\hline Variable & Mean & SD & Min & Max \\
\hline Average Population Income & $\$ 71,837$ & $\$ 25,856$ & $\begin{array}{l}\$ 13,11 \\
7\end{array}$ & $\$ 418,374$ \\
\hline Public School Funding & $\begin{array}{l}\$ 74,300,00 \\
0\end{array}$ & $\begin{array}{l}\$ 331,000,00 \\
0\end{array}$ & $\begin{array}{l}\$ 18,00 \\
0\end{array}$ & $\begin{array}{l}\$ 27,400,000,00 \\
0\end{array}$ \\
\hline Poverty & $10.36 \%$ & $6.65 \%$ & $0 \%$ & $100 \%$ \\
\hline Average Population Education & $22.8 \%$ & $12.37 \%$ & $0 \%$ & $100 \%$ \\
\hline Ethnic Diversity of Community & $77.92 \%$ & $21.76 \%$ & $0 \%$ & $100 \%$ \\
\hline Average Enrollment & 6,561 & $24,727.35$ & 1 & 13,872 \\
\hline $\begin{array}{l}\text { Lowest Grade Served by } \\
\text { Charter }\end{array}$ & $2^{\text {nd }}$ Grade & 3.87 Grades & Pre-K & $12^{\text {th }}$ Grade \\
\hline $\begin{array}{l}\text { Highest Grade Served by } \\
\text { Charter }\end{array}$ & $8^{\text {th }}$ Grade & 2.97 Grades & Pre-K & $12^{\text {th }}$ Grade \\
\hline $\begin{array}{l}\text { Ethnic Diversity of Charter } \\
\text { School }\end{array}$ & $72.6 \%$ & $27.2 \%$ & $0 \%$ & $100 \%$ \\
\hline
\end{tabular}

Observations: ---

Data drawn from 2015/16 NCES CCD and EDGE datasets, the US Census, and the NAPCS

This model begins with calculating the relationships of the non-financial variables followed by adding financial demographics to identify differences between the community impact and the impact of the school itself. More variables are included than in the previous analysis to account for charter school-specific characteristics that could influence the success of the school. The data for this model is from the 2014/15 and 2015/16 academic school years.

\section{Results}

The results of Analysis 1 are presented in Table 3. A chi square test comparing Models 1 and 2 calculated that adding each financial variable in Model 2 improves model 
fit significantly $(\operatorname{chi} 2(2)=6.44, \mathrm{p}<0.05)$. As shown, when accounting for both control and financial variables, the only significant predictor is the diversity of the community $(\mathrm{z}=-5.4, \mathrm{p}<0.001)$. After adding the financial variables, the significance of the diversity of a community remained virtually unchanged. After converting the log odds to an odds ratio, the model predicts that as a community becomes more homogenously white, there is a decrease in the odds of a charter school being created (95\% CI [0.953, 0.978]).

Enrollment was originally significant; however; when adding the financial variables, the predicted significance of enrollment decreased greatly.

\section{Table 3. $\quad$ Logistic Regression Results Analysis 1}

\begin{tabular}{|c|c|c|}
\hline Variable & Model 1 & Model 2 \\
\hline \multirow[t]{2}{*}{ Enrollment } & $0.00 * *$ & -0.00 \\
\hline & $(1.0)$ & $(0.99)$ \\
\hline \multirow[t]{2}{*}{ Ethnic Diversity of Community } & $-0.029 * *$ & $-0.035 * *$ \\
\hline & $(0.97)$ & $(0.96)$ \\
\hline \multirow[t]{2}{*}{ Average Population Education } & 0.016 & -0.008 \\
\hline & $(1.016)$ & $(0.99)$ \\
\hline \multirow[t]{2}{*}{ Average Population Income } & & 0.00 \\
\hline & & $(1.0)$ \\
\hline \multirow[t]{2}{*}{ Public School Funding } & & 0.00 \\
\hline & & $(1.0)$ \\
\hline \multirow[t]{2}{*}{ Poverty } & & -0.038 \\
\hline & & $(0.96)$ \\
\hline \multicolumn{3}{|c|}{$\begin{array}{l}\text { Unstandardized logistic coefficients with odds ratios in parentheses } \\
\text { Model } 1 \text { includes control variables, Model } 2 \text { adds financial variables } \\
{ }^{*} \mathrm{p}<.05,{ }^{* *} \mathrm{p}<.01, * * * \mathrm{p}<.001\end{array}$} \\
\hline
\end{tabular}


rural areas across the United States $(0.2 \%)$. This small sample size makes it difficult to compare variables and confidently predict future results.

Analysis 2, as seen in Table 4, had a larger sample size of 682 charter school communities, as it included all charter schools operating in 2015/16. After considering all variables in this model, four out of nine were calculated as significant at the $p<0.001$ level and another three were calculated as significant at the $\mathrm{p}<0.05$ level. Enrollment and Income were the only two variables calculated as not significant in predicting a community's ability to sustain a charter school. The addition off all financial variables in Model 2 was shown to improve model fit significantly $(\mathrm{p}<0.001)$ when comparing chi squares $(\operatorname{chi} 2(2)=54.68)$. 
Table 4. $\quad$ Logistic Regression Results Analysis 2

\begin{tabular}{|c|c|c|}
\hline Variable & Model 1 & Model 2 \\
\hline \multirow[t]{2}{*}{ Enrollment } & -0.001 & -0.001 \\
\hline & $(0.99)$ & $(1.0)$ \\
\hline \multirow[t]{2}{*}{ Average Population Education } & $0.04 * *$ & $0.03 * *$ \\
\hline & $(1.04)$ & $(1.0)$ \\
\hline \multirow[t]{2}{*}{ Diversity of Community } & $-0.01 * *$ & $-0.02 * *$ \\
\hline & $(0.99)$ & $(0.99)$ \\
\hline \multirow[t]{2}{*}{ Lowest Grade Served by Charter } & $-0.18 * *$ & $-0.18 * *$ \\
\hline & $(0.84)$ & $(0.84)$ \\
\hline \multirow[t]{2}{*}{ Highest Grade Served by Charter } & $0.3 * *$ & $0.3 * *$ \\
\hline & $(1.33)$ & $(1.34)$ \\
\hline \multirow[t]{2}{*}{ Diversity of Charter School } & $-0.75^{* *}$ & $-0.75^{*}$ \\
\hline & $(1.0)$ & $(0.99)$ \\
\hline \multirow[t]{2}{*}{ Average Population Income } & & 0.00 \\
\hline & & $(1.0)$ \\
\hline \multirow[t]{2}{*}{ Public School Funding } & & $0.00 * *$ \\
\hline & & $(1.0)$ \\
\hline \multirow[t]{2}{*}{ Poverty } & & $-0.03 *$ \\
\hline & & $(0.97)$ \\
\hline
\end{tabular}

\footnotetext{
Unstandardized logistic coefficients with odds ratios in parentheses

Model 1 includes the same control variables as Analysis 1 but also adds school-level variable, Model 2 adds financial variables

$* \mathrm{p}<.05, * * \mathrm{p}<.001$
}

Both Diversity of Community $(\mathrm{z}=-2.37)$ and Diversity of School $(\mathrm{z}=-2.83)$ were significant at the $\mathrm{p}<0.05$ level and similar to Analysis 1, demonstrate that when the diversity in a community $(95 \%$ CI $[0.985,0.999])$ and in a charter school (95\% CI [0.997, 0.999]) increases by one percent, the odds of sustaining a charter school differs by a factor of 1.01 and 1.28 respectively. Poverty was also found to be significant at the $\mathrm{p}<$ 
0.05 level $(\mathrm{z}=-10.33)$. The odds of sustaining a charter school increased by a factor of 0.97 as poverty in a community increased by one percent $(95 \% \mathrm{CI}[0.95,0.99])$. Average Population Education ( $\mathrm{z}=4.12)$, Lowest Grade Served by Charter $(\mathrm{z}=-10.52)$, Highest Grade Served by Charter ( $\mathrm{z}=13.27)$, and Funding ( $\mathrm{z}=6.62)$, were all found to be significant at the $\mathrm{p}<0.001$ level. As the population education increases, the odds of sustaining a charter school increase by a factor of 1.03 (95\% CI [1.01, 1.04]). A charter school serving a grade lower than another would have increased odds of operating another year by a factor of $0.84(95 \%$ CI $[0.81,0.87])$ and a charter school serving a grade higher than another increases the odds of being sustained by a factor of 1.34 (95\% CI $[1.28,1.40])$. As school funding increases by one unit, the odds of sustaining a charter school increase by a factor of one (95\% CI [1,1]). 


\section{DISCUSSION}

The results of the Analysis 1 in this feasibility study show that the selected financial characteristics of a community do not influence a community's ability to create a charter school. Analysis 2 found that the poverty of a community and school funding can impact the ability of a community to continue operating. The significance of school funding sheds light on the argument discussed in the literature review of the influence of public funding suggesting public funds available can be detrimental to continued operation of a charter school.

Analysis 1 and 2 found that social demographics such as population education, grades served by charters, and community and school diversity significantly impact the feasibility of creating and sustaining charter schools. Increased education levels in the community improves the chances of charter schools remaining in a community. This supports past research regarding the necessity of human capital to produce charter schools (Mead et al., 2015; Stuit \& Doan, 2012). The impact of increased diversity in rural areas and its proportional effect on the likelihood of charter schools being created and sustained could be researched further. More thorough research in this area would add insights into the debate of whether or not charter schools provide an equitable education (Dingerson et al., 2008; Ladd \& Singleton, 2017; May 2006). Future feasibility studies should focus on other social and political elements in a community that could influence school choice such as the main industry of the community, crime rates, political affiliations, and employment rate. 
Overall, the findings, though significant, showed minimal impact by the variables. The study was limited by the number of charter schools created in the chosen year. As charter schools become more popular, the number created in rural areas each year could increase, finding a year with a larger number of charter schools being created and creating a model that measured multiple years would improve confidence and decrease error associated with small sample sizes. Further, a cluster analysis rather than logistic regression could be valuable in future research for identifying the types of communities with capacity for creating a charter school. 


\section{CONCLUSION}

The importance of school choice is a large part of the current policy conversation and is a priority for parents across the country (Kaplan \& Owings, 2018). Rural communities are often not considered in policy conversations as areas that have needs unique from urban areas (Johnson \& Howley, 2015; Smarick, 2014). Performing feasibility studies can help understand the ability for new policies and interventions, such as charter schools, to expand to new areas based on their current resources (Bowen et al., 2009). Community characteristics have been shown to impact student performance and school success as much as individual school characteristics (Bodine et al., 2008; Reeves, 2012). This research chose to focus on financial factors of a community because of the many financial challenges found in research regarding education in rural areas (Arsen \& Ni, 2012; Cohodes, 2018; Schafft et al., 2014).

This study found that the chosen financial factors did not play a role in the likelihood of the creation and sustaining of charter schools in rural areas. However, the research did provide evidence that other social characteristics of communities do significantly impact charter schools. Future feasibility studies should focus on social and political factors of rural communities to create and sustain charter schools to better understand the potential for school choice in all areas in the United States. 


\section{REFERENCES}

Arain, M., Campbell, M. J., Cooper, C. L., \& Lancaster, G. A. (2010). What is a pilot or feasibility study? A review of current practice and editorial policy. BMC medical research methodology, 10(1), 67.

Arsen, D., \& Ni, Y. (2012). The effects of charter school competition on school district resource allocation. Educational Administration Quarterly, 48(1), 3-38.

Bagley, C., Woods, P. A., \& Glatter, R. (2001). Rejecting schools: Towards a fuller understanding of the process of parental choice. School leadership \& management, 21(3), 309-325.

Biddle, C., \& Azano, A. P. (2016). Constructing and reconstructing the "rural school problem" A century of rural education research. Review of Research in Education, 40(1), 298-325.

Bingler, S., Diamond, B. M., Hill, B., Hoffman, J. L., Howley, C. B., Lawrence, B. K., \& Washor, E. (2002). Dollars \& Sense: The Cost Effectiveness of Small Schools.

Bodine, E., Fuller, B., González, M. F., Huerta, L., Naughton, S., Park, S., \& Teh, L. W. (2008). Disparities in charter school resources-The influence of state policy and community. Journal of Education Policy, 23(1), 1-33.

Bowen, D. J., Kreuter, M., Spring, B., Cofta-Woerpel, L., Linnan, L., Weiner, D., \& Fernandez, M. (2009). How we design feasibility studies. American journal of preventive medicine, 36(5), 452-457.

Brimley, V., Garfield, R. R., \& Verstegen, D. A. (2005). Financing education in a climate of change.

Bryant Jr, J. A. (2010). Dismantling Rural Stereotypes. Educational Leadership, 68(3), 54-58.

CREDO. (2013). National charter school study 2013. 
CREDO. (2013a). Charter School Performance in Louisiana.

CREDO. (2014). Charter School Performance in California.

CREDO. (2014a). Charter School Performance in Ohio.

CREDO. (2015). Online Charter School Study.

CREDO. (2017). Charter School Performance in Texas.

CREDO. (2019). Charter School Performance in Idaho.

Collins, T. (1999). Charter schools: an approach for rural education?. Clearinghouse on Rural Education and Small Schools, Appalachia Educational Laboratory.

Cohodes, S. (2018). Charter Schools and the Achievement Gap. The Future of Children, $1-16$.

Darling-Hammond, L., \& Montgomery, K. (2008). Keeping the promise: The role of policy in reform. Keeping the promise, 91-110.

David, R., Hesla, K., \& Pendergrass, S. A. (2017). A Growing Movement: America's Largest Public Charter School Communities. National Alliance for Public Charter Schools.

DeVos, B. (2019, February 28). Prepared remarks of secretary DeVos at the unveiling of the Education Freedom Scholarships proposal. U.S. Department of Education. https://www.ed.gov/news/speeches/prepared-remarks-secretary-devos-unveilingeducation-freedom-scholarships-proposal

Dingerson, L., Peterson, B., Walters, S., \& Miner, B. (Eds.). (2008). Keeping the promise?: The debate over charter schools. Rethinking Schools.

Epple, D., Romano, R., \& Zimmer, R. (2016). Charter schools: A survey of research on their characteristics and effectiveness. In Handbook of the Economics of Education(Vol. 5, pp. 139-208). Elsevier.

Farmer, S., Baber, A., \& Poulos, C. (2017). Charter School Expansion, School Closures, and Fiscal Stress in Chicago Public Schools. 
Fishman, D. (2015). School reform for rural America: innovate with charters, expand career and technical education. Education Next, 15(3), 8-17.

Forman Jr, J. (2004). The secret history of school choice: How progressives got there first. Geo. LJ, 93, 1287.

Good, T. L., \& Braden, J. S. (2014). The great school debate: Choice, vouchers, and charters. Routledge.

Howley, A., Howley, M., Hendrickson, K., Belcher, J., \& Howley, C. (2012). Stretching to Survive: District Autonomy in an Age of Dwindling Resources. Journal of Research in Rural Education, 27(3).

Howley, C., Johnson, J., \& Petrie, J. (2011). Consolidation of Schools and Districts: What the Research Says and What It Means. National education policy center.

Irvin, M. J., Meece, J. L., Byun, S. Y., Farmer, T. W., \& Hutchins, B. C. (2011). Relationship of school context to rural youth's educational achievement and aspirations. Journal of youth and adolescence, 40(9), 1225.

Johnson, J., \& Howley, C. B. (2015). Contemporary federal education policy and rural schools: A critical policy analysis. Peabody Journal of Education, 90(2), 224-241.

Kaplan, L. S., \& Owings, W. A. (2018). Funding School Choice: Implications for American Education. Journal of Education Finance, 44(2), 199-217.

Ladd, H. F., \& Singleton, J. D. (2017). The fiscal externalities of charter schools: Evidence from North Carolina. Education Finance and Policy, 1-34.

Mathis, W. J. (2003). Financial challenges, adequacy, and equity in rural schools and communities. Journal of Education Finance, 29(2), 119-136.

May, J. J. (2006). The charter school allure: Can traditional schools measure up?. Education and Urban Society, 39(1), 19-45.

McCarthy, M. (2016). Parental choice of school by rural and remote parents. Issues in Educational Research, 26(1), 29. 
McFarland, J., Hussar, B., Wang, X., Zhang, J., Wang, K., Rathbun, A., ... \& Mann, F. B. (2018). The Condition of Education 2018. NCES 2018-144. National Center for Education Statistics.

Mead, S., Mitchel, A. L., \& Rotherham, A. J. (2015). The state of the charter school movement. Bellwether Education Partners.

Merry, M. S., \& New, W. S. (2017). Is the liberal defense of public schools a fantasy?. Critical Studies in Education, 58(3), 373-389.

Miller, P. M., Scanlan, M. K., \& Phillippo, K. (2017). Rural cross-sector collaboration: A social frontier analysis. American Educational Research Journal, 54(1_suppl), 193S-215S.

National Alliance for Public Charter Schools (2019). Charter school datasets data dashboard. National Alliance for Public Charter Schools. https://data.publiccharters.org/

NCES (n.d). Rural Education in America. National Center for Education Statistics. https://nces.ed.gov/surveys/ruraled/definitions.asp

Ni, Y. (2009). The impact of charter schools on the efficiency of traditional public schools: Evidence from Michigan. Economics of Education Review, 28(5), 571584.

Pazhouh, R., Lake, R., \& Miller, L. (2015). The Policy Framework for Online Charter Schools. Center on Reinventing Public Education.

Ratcliffe, M., Burd, C., Holder, K., \& Fields, A. (2016). Defining rural at the US Census Bureau. American community survey and geography brief, 1-8.

Redford, J., Battle, D., and Bielick, S. (2017). Homeschooling in the United States: 2012 (NCES 2016-096REV). National Center for Education Statistics, Institute of Education Sciences, U.S. Department of Education. Washington, DC.

Reeves, E. B. (2012). The effects of opportunity to learn, family socioeconomic status, and friends on the rural math achievement gap in high school. American behavioral scientist, 56(7), 887-907. 
Ridley, M., \& Terrier, C. (2018). Fiscal and education spillovers from charter school expansion (No. w25070). National Bureau of Economic Research.9

Rose, C. P., Maranto, R., \& Ritter, G. W. (2017). From the Delta Banks to the Upper Ranks: An Evaluation of KIPP Charter Schools in Rural Arkansas. Educational Policy, 31(2), 180-201.

Schafft, K. A., \& Jackson, A. Y. (2010). Rural education for the twenty-first century: Identity, place, and community in a globalizing world. Penn State Press.

Schafft, K. A., Frankenberg, E., Fuller, E., Hartman, W., Kotok, S., \& Mann, B. (2014). Assessing the enrollment trends and financial impacts of charter schools on rural and non-rural school districts in Pennsylvania. The Center for Rural Pennsylvania, Retrieved May, 13(2015), 488-498.

Sherman, J., \& Sage, R. (2011). Sending Off All Your Good Treasures: Rural Schools, Brain Drain, and Community Survival in the Wake of Economic Collapse. Journal of Research in Rural Education, 26.

Smarick, A. (2014). A New Frontier: Utilizing Charter Schooling to Strengthen Rural Education. Bellwether Education Partners.

Smith, N. and Westapher, E. (2017). Virtual Charter School Accountability: What We Can Do Now. National Charter School Resource Center.

Strange, M. (2011). Finding fairness for rural students. Phi Delta Kappan, 92(6), 8-15. Stuit, D., \& Doan, S. (2012). Beyond City Limits: Expanding Public Charter Schools in Rural America. Issue Brief. National Alliance for Public Charter Schools.

Stuit, D., \& Doan, S. (2012). Beyond City Limits: Expanding Public Charter Schools in Rural America. Issue Brief. National Alliance for Public Charter Schools.

Timpane, M., Brewer, D., Gill, B., \& Ross, K. (2001). Rhetoric vs. reality: What we know and what we need to know about vouchers and charter schools. Rand Corporation. 
U.S. Department of Education, National Center for Education Statistics. (2018). The Condition of Education 2017.

U.S. Department of Education (2019, March 11). President's budget expands education freedom, supports teachers, protects vulnerable students. U.S. Department of Education. https://www.ed.gov/news/press-releases/presidents-budget-expandseducation-freedom-supports-teachers-protects-vulnerable-students

Vergari, S. (2007). The politics of charter schools. Educational Policy, 21(1), 15-39. Www.kipp.org (2019). Creating joyful, academically excellent schools. KIPP. https://www.kipp.org/kipp-foundation/ 